ERLUNDH-EHRENBERG, Carin. 1963. Genetic variation in progeny tests of Scots pine (Pinus silvestris L.). Seud. Forest. Suecica $10.135 \mathrm{p}$.

NILSSON, Bo. 1963. Studier av avkommor efter korsning mellan gran av svensk och mellaneuropeisk proveniens. In Föreningen Skogsträdsförädling Arsbok 1963. Appendix, p. 1-23.

SARVAS, Risto. 1962. Investigations on the flowering and seed crop of Pinus silvestris. Comm. Inst. Forest. Fenniae 53 (4) : 1-19s.

\title{
MeEting of National Committee on Forest Land ${ }^{1}$
}

One year ago, almost to the day, I had the opportunity to address the national meeting which was called to adopt a land capability classification for forestry for the Canada Land Inventory Program of ARDA. Many of you who are present today were at that meeting and will recall my recommendation that the proposed committee for periodic revision of the Capability Classification be constituted with broadened terms of reference to enable it to become a National Forest Land Committee which would act in an advisory capacity to the Department of Forestry.

The Organizing Committee, consisting of Mr. Hills, Mr. Lacate, Dr. Louis Rousseau, Dr. Rowe and our Chairman, deserve a great deal of credit for the speed and thoroughness with which they acted, and I would like to publicly acknowledge their efforts. The fact that we are meeting today as an established Committee one year after the idea was discussed is a tribute both to the interest in the field of land classification and the hard work of all of you.

I am honoured to have been asked to serve as your Honorary Chairman. As most of you know, the field we are discussing has been of primary interest to me for most of my life.

I note from the Agenda that delegates from each of the provinces will be reporting progress of their forest land capability program and will also be expressing, among other things, their Provinces' views on whether a type of program such as this should be extended to classify all lands whose use-capability is primarily forestry.

Forestry is basically land-management, and as Foresters we have a major responsibility for the management of the largest areal part of Canada. We must realize, however, that this responsibility now encompasses more than the production of wood fibre. In the affluent society which we serve, there is an increasing demand for treed land for uses such as parks, water conservation, recreation and wildlife. It would be sheer folly to ignore these demands in our planning processes. Furthermore, nothing will be gained by dedicating land to forest production, only to have it removed from that use after only a few years. The forester as land manager must be aware of all the values that pertain to the areas under his control.

Since land must usually be managed for a primary use, though with secondary complementary uses, it is necessary to take inventory of the landscape as it exists in terms of vegetation and soil, providing maps of the physical characteristics which determine the suitability for alternate uses. It needs to be stressed that basic to any system of land planning of this

${ }^{3}$ An address by Dr. L. Z. Rousseau, Deputy Minister of Forestry for Canada, to tho opening session of The Committee, January 26, 1966, Ottawa. 
nature is a physical land classification system which lends itself to interpretation for use-capability. This committee then has a major responsibility in the vital field of land management.

I am aware that land management falls within the jurisdictional field of the provinces and it may well be that not all of the provinces feel the need of undertaking a program of wildland classification at this stage. This is inevitable in a country of such varying conditions. However, as a national research organization, the Department of Forestry has a responsibility to encourage proper land use and to provide the technical assistance necessary to achieve it. The Department has recognized this responsibility, and, during the past year has recruited eight additional professionals and eight additional technicians to work in the field of forest land classification. During 1966-67 we shall be recruiting some eighteen additional professionals to work in the field of forest soils and forest land classification research. Thus, we are now prepared to work jointly or co-operatively with any province which is interested in developing the techniques for, and initiating, a land inventory in its forested zones.

Any contemplated program of wild land inventory should be planned with a full awareness of current land and soils research and of the availabiltiy of trained personnel. This Committee will therefore perform a useful function in examining the status of forest soils research in Canada and the facilities and prospects for ensuring a supply of trained "conservationists" for wild land management.

It may well be that the Department is overlooking possibilities in which we should become involved. Thus, we are very interested in the recommendations which will come out of this Committee and its sub-committees. I would like to assure you that the Department of Forestry will consider your recommendations very carefully and will treat them with the seriousness which you rightly expect.

May I take this opportunity to congratulate you on the establishment of this excellent Committee, and to wish you the best of luck at this, your initial meeting.

\section{Comments on CANADA LAND Inventory}

The inventory has been described in this issue by R. J. McCormack as Coordinator of the Forestry Sector. Mr. McCormack served as Chairman of the Forest Land Committee described in the Dec. 1965 issue of the Forestry Chronicle and mentioned above. The land capability study started in 1963 under ARDA will continue until 1969 and will cost an estimated $\$ 18,000,000$. To date, from 15 to 20 thousand of some 100 thousand square miles have been mapped.

Lack of trained personnel, the need for further education, the possibility of extending the program to all forest lands, need to further define objectives of the Canadian Land Inventory, and need for supporting research in forest mensuration, soils, and ecology were discussed by the Committee on Forest Land. Papers by Lacate on land inventory methods and by Hills on philosophy of physiographic site mapping are scheduled to appear in the June issue of the Chronicle. Expansion of studies of socio-economic aspects 